\title{
Der Weg nach Rio in Brazil: Histoire Croisée, Public Diplomacy and Film-Historical Research
}

\begin{abstract}
The article discusses the relevance of the histoire croisée approach that has been only marginally applied to film and cinema historical research. Histoire croisée is an approach to write history from a transnational perspective. It tries to overcome the conceptual shortcomings of comparative and transfer studies and integrates them into its theoretical framework. The case study of a cultural-diplomatic conflict between Brazil and Germany illustrates some of the methodological advantages of the histoire croisée approach. The paper argues that writing historiography from a transnational perspective opens not only new areas of film historical research, it also offers a better understanding of film historical events that otherwise might be overlooked by comparative or transfer studies.
\end{abstract}

\section{Keywords}

Brazil; diplomacy; histoire croisée; historiography; transnational

On 17 March 1931, the Brazilian newspaper Diário de Noticias, based in Rio de Janeiro, published a front-page article with the lurid headline 'A Film Insulting For Brazil and Its Civilization.'12 The article reported the screening of the German film Der Weg nach Rio/Road to Rio (Manfred Noa, DE 1931), a white slavery genre film, which, according to the journalist, depicted Brazil in a derogatory manner and the countries' then capital as the international centre of white slavery. ${ }^{3}$

Der Weg nach Rio was never screened in Brazil but only viewed by a small number of Brazilians living in Berlin at the time of its release. However, the article made the film the talk of the day in Brazil. The public outrage it generated most likely resulted in one of the most severe cultural-diplomatic conflicts between the two countries

The following article investigates the history of the film and analyses why it became a public scandal in Brazil. It situates the film in a German cultural-historical context before discussing the 
diplomatic debate surrounding it. The analysis is based on research at the Political Archive of the Federal Foreign Office in Berlin and the Archivo Histórico de Itamaraty in Río de Janeiro, the historical archive of the Brazilian Foreign Office. In combination with reviews and articles from German and Brazilian film journals and newspapers, the case study is situated at the crossroads of cultural history, public diplomacy and Brazil's cultural-political project of the early thirties. To explore the different

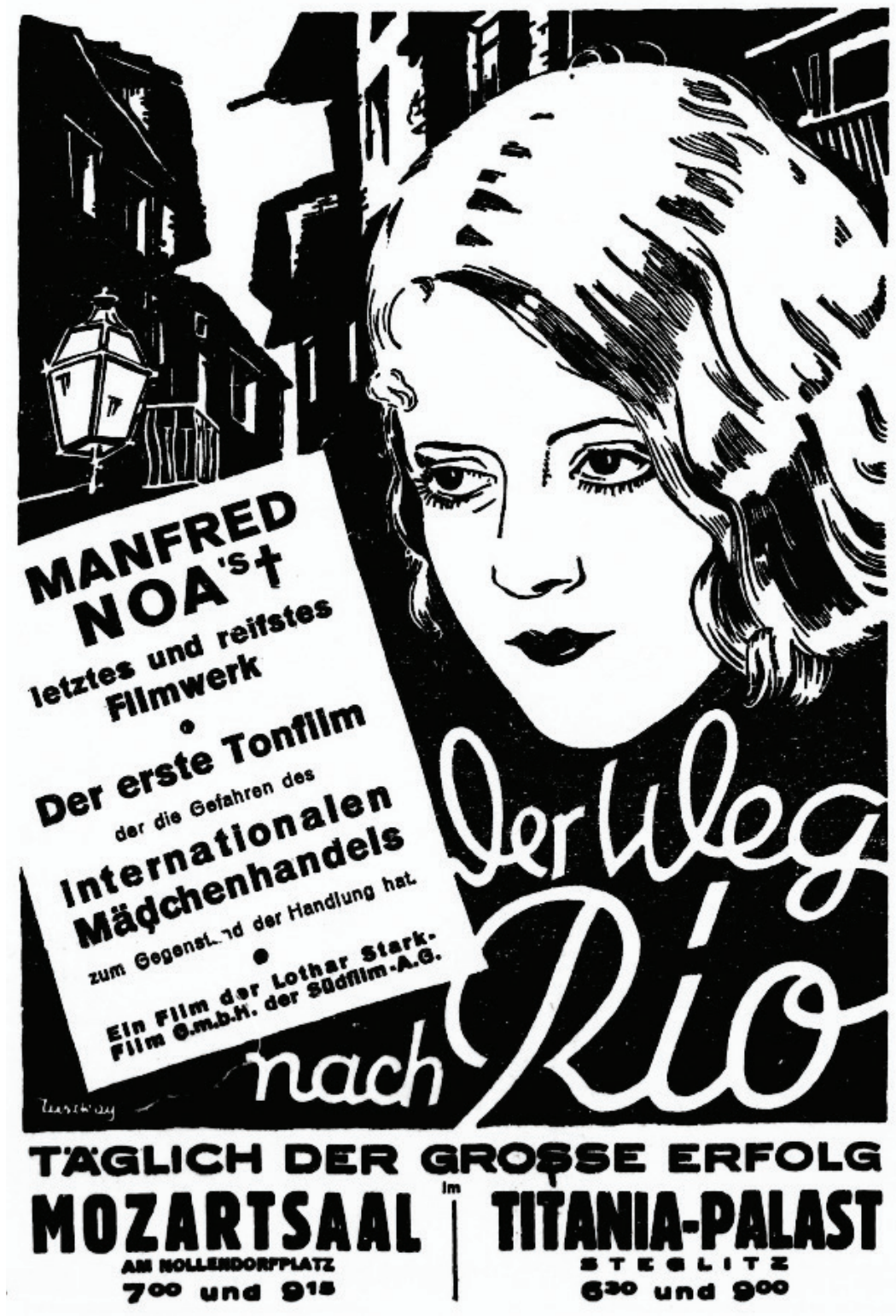


discourses that frame the case study, the analysis adopts Michael Werner and Bénédicte Zimmermann's multi-perspective histoire croisée approach. In so doing, it introduces a method that goes beyond the traditional approaches of comparison and transfer to achieve a complex understanding of Der Weg nach Rio as a transnational historical event.

\section{Comparison and histoire croisée}

In their article comparing historical cinema cultures, Daniel Biltereyst, Thunnis van Oort, and Philippe Meers note that 'comparative research is only weakly developed within film and cinema studies. ${ }^{4}$ Comparative studies in New Cinema History may still be in its infancy, but the number of projects that are regularly presented at the annual HoMER conferences demonstrates the prodigious output of this research perspective. The amount of data on cinema-going available today due to digitisation projects and digital archives offer research conditions which did not exist just a decade ago. The analysis of Der Weg nach Rio would not have been feasible without the OCR-based Hemeroteca Digital Brasileira, with more than ten million pages of newspapers and journals. ${ }^{5}$ As the case study on Der Weg nach Rio shows, the public discussion about the film did not take place in film journals but rather newspapers. The Hemeroteca has become an indispensable research tool for anybody studying Brazilian film and cinema history.

A comparative perspective in cinema historical research attempts 'to understand larger trends, factors, or conditions explaining differences and similarities in historical cinema cultures. ${ }^{6}$ A comparison between two cinema cultures transcends national borders and brings, tentatively speaking, nations into a dialogue. However, comparison is not the only approach that breaks up national perspectives. Historians Heinz-Gerhard Haupt and Jürgen Kocka have pointed out that 'in recent years, a different mode of extending historical study beyond national borders has gained much ground, in different forms and under different labels, such as history of transfer, entangled histories or history of entanglement, connected history, histoire croisée and Verflechtungsgeschichte. ${ }^{7}$ They can all be subsumed under the notion of transnational history. Historians often view comparative history and transnational history as opposing concepts, but, as historian Hartmut Kaelble remarks, it does not make sense to artificially separate both approaches, because they are based on the same motivation, 'writing history that extends beyond the nation-state'. ${ }^{8}$ 
Critiques of comparative history have argued that one of its pitfalls is that a comparison has to construct its objects of research as entities first, and thereby promotes the establishment of dichotomies ${ }^{9}$ : 'From an entangled-history point of view, comparison appears a bit too mechanistic, a bit too analytical in that it separates reality into different pieces in order to analyse, that is, to compare the pieces as units of comparison, whereas it would be necessary to see them as one, as one web of entanglements (...). ${ }^{10}$

Werner and Zimmermann's histoire croisée approach originated as a means for addressing the shortcomings in the comparative method and transfer studies, but it nonetheless draws heavily on the two approaches. ${ }^{11}$ Histoire croisée is often translated as entangled history, but Werner and Zimmerman simply term it 'crossed history'. ${ }^{12}$ Originally written in German in 2002, translations in French and English have ensured its wide reception in the social and human sciences. Werner and Zimmermann define it as belonging "to the family of "relational" approaches that, in the manner of comparative approaches and studies of transfers (most recently of "connected" and "shared history”) examines the links between various historically constituted formations. ${ }^{13}$

Although transnational film studies have recently been established as a sub-discipline in film studies, histoire croisée has been marginally applied to film historical or (new) cinema historical research as 'media dimensions have been strangely absent in the discussion on histoire croisée and global history. ${ }^{\cdot 14}$ Applying the histoire croisée approach in historical research means adopting and crossing different perspectives and research cultures, which implies the mastery of the different languages involved in the research. What distinguishes histoire croisée from comparison and transfer is, therefore, the 'multiplicity of possible viewpoints and the divergences resulting from languages, terminologies, categorizations and conceptualizations, traditions, and disciplinary usages. (...) In contrast to the mere restitution of an "already there", histoire croisée places emphasis on what, in a self-reflexive process, can be generative of meaning. ${ }^{15}$

Werner and Zimmerman do not consider histoire croissée as a counterapproach to comparison and transfer but rather as a toolbox that integrates their methodological contributions. In contrast to comparison or transfer, which are ultimately static models and cannot overcome 'the tension between the method and the object,' histoire croisée proposes a pragmatic induction, which 'implies to start from the object of study and the situations in which it is embedded, according to one or more points of view- previously defined, it is true, but subject to continual readjustments in the course of empirical investigation. ${ }^{16}$ Crossing and intercrossing have effects and repercussions; they can cause 
transformations and are based on reciprocity and asymmetry. These aspects can be observed in history and need to be considered in historical research: 'To investigate relational configurations that are active and asymmetrical, as well as the labile and evolving nature of things and situations, to scrutinize not only novelty but also change is one of the aims of histoire croisée. ${ }^{17}$

Biltereyst and Meers' remark that 'cinema's complexity as an economic, societal and cultural institution might be seen to complicate and encumber comparison over time and place' ${ }^{18}$ makes a perfect argument for a multidimensional approach, as is proposed by the histoire croisée method.

The case study on Der Weg nach Rio is part of a larger research project on German-Brazilian transnational relations in film and cinema history. It does not claim to present histoire croisée in all its complexity, but rather it shows how the combination of different perspectives produces a more comprehensive understanding of the film's history than a national distribution history of the film would be capable of.

Following the pragmatic and inductive approach that Werner and Zimmerman propose, the research into the film's history began with a research question that changed several times during the research process. The beginning of the project on German-Brazilian film relations was denoted by a compilation of a filmography that included films from both nations that dealt with the other country: How is the other country depicted in the film? A film title such as Der Weg nach Rio was obviously about the Brazilian city, then its capital. It produced a certain image of the country for the German film audience at a specific time in German film history. Until that point, the analysis of the film did not require a Brazilian perspective. During a research stay at the Political Archive of the Federal Foreign Office in Berlin, records indicated that the film caused a diplomatic dispute between Germany and Brazil at the time of its release. ${ }^{19}$

More interesting than the aesthetic and narrative aspects of the film became the question of why this specific film caused a diplomatic controversy. The whole dimension of this dispute took shape with a further research stay at the Archivo Histórico de Itamaraty in Río de Janeiro, the historical archive of the Brazilian Foreign Office, accompanied by the study of the Brazilian daily press of the film at that time. It turned out that the diplomatic dispute was closely related to the work of the journalist who triggered the public outrage in Brazil; but more than this it showed that this journalist was working as a Brazilian diplomat and following a cultural-political agenda that aimed to place Brazil in the pantheon of cultural nations as opposed to a shelter for international white slavers. Der Weg nach Rio, therefore, was not simply a film of the popular white slavery genre but also an early example of public diplomacy. The film's history began in Germany but ended in Brazil. 


\section{Soft power and film}

Research into the historical archives of the two Foreign Offices has highlighted the relevance of diplomatic correspondence. Research on the relationship between public diplomacy, also known as soft power, and film is still limited, but since the end of World War II, cultural products such as literature, photography or audio-visual media have become alternatives to hard power, an example of which is military threat. Joseph Nye, who coined the term in the late 1980s, defines soft power as 'the ability to get what you want through attraction rather than coercion or payments. It arises from the attractiveness of a country's culture, political ideals, and policies' ${ }^{20}$ and 'rests on the ability to shape the preferences of others. ${ }^{21}$ Soft power usually is associated with Hollywood and its global reach, but studies on Indian or Chinese cinema have also shown the significance of film as a political tool. ${ }^{22}$ The strong opposition of the Brazilian government to Der Weg nach Rio is an example of how the modern medium of film was a centre of diplomatic debates prior to World War II and the Cold War.

Although Brazil did not release Brazilian films to the German public to counter German or European white slavery films, Brazil's diplomatic pressure made the German distributor of Der Weg nach Rio release German films about Brazil in the German cinemas. Much more in the sense of soft power was Brazil's readjustment of its cultural-political discourse. Beginning with the era of Getulio Vargas in the 1930s, Brazil aimed to establish the country as a global cultural nation and supported the publicising of Brazilian culture abroad, such as Brazilian music. ${ }^{23}$ To be known in the world for organised white slavery was not something Brazil would tolerate.

Brazil and Germany traditionally enjoyed solid economic and diplomatic relations. Between 1818 and the late 1920s, almost two hundred thousand German immigrants came to Brazil. ${ }^{24}$ The increase of Brazilians of German origin in the country, the so-called Teuto-Brasileiros, went hand-in-hand with growing German investment in Brazil. ${ }^{25}$ Interrupted only by World War I, Germany was continuously one of the most important trading partners in the Brazilian economy, and neither Brazil nor Germany had any interest in downgrading their relations through any diplomatic disputes.

In contrast to Brazilian products such as coffee, sugar, tobacco or leather, only a very small number of Brazilian films reached German screens prior to World War II. In 1929, just 10,900 meters of exposured film material entered the German market. ${ }^{26}$ There is no indication that Brazilian feature film productions such as São Paulo- Sinfonia da metrópole (Rodolfo Lustig, Adalberto Kemeny, BR 
1929) or Mário Peixoto’s Limite (BR 1931), today considered classics of Brazilian silent cinema, were shown in German cinemas.

Just as Germany was an important target country for Brazilian goods, Brazil became an interesting market for the German film industry after World War I. In contrast to the period before Great War, in which American productions only played a minor role in the South American market ${ }^{27}$, US productions began to dominate the continent thereafter. At the end of the 1920s, they constituted $85.9 \%$ of the national Brazilian market. ${ }^{28}$ German productions had a stable second place with $7.7 \%$ of the market and enjoyed an excellent reputation in the country, especially in the south of Brazil, where most of the German immigrants lived. ${ }^{29}$ However, annual reports and minutes of the board meeting of the Universum Film AG (UFA) show that the German film industry did not want to be a bit player in the South American market but continuously attempted to expand in it. ${ }^{30}$ A significant step in Ufa's expanding presence in Brazil was the opening of a Ufa Palácio, similar to the Berlin Ufa Palast, in the heart of Sao Paulo in November $1936 .{ }^{31}$ Other cinema palaces were set to follow.

\section{Der Weg nach Rio: A popular European genre film}

Der Weg nach Rio (1931) tells the story of the young shorthand typist Inge (Maria Matray) who dreams of driving a big limousine. She convinces her friend Karl (Oskar Marion), who works at a garage, to take her out in the limousine of a rich customer. On their tour, Inge runs over a child who unexpectedly runs onto the street. Afraid of the penitentiary, the couple flee the scene and find shelter in a shabby boarding house in Hamburg. Through the dubious pension landlady (Senta Söneland), Inge becomes acquainted with the businessman Ricardo Gabiano (Oskar Homolka), who offers her a job at his office in Rio de Janeiro. While Inge follows Gabiano to Brazil, the landlady betrays Karl to the police for the reward. In Rio de Janeiro, Inge realises that she has been the victim of a girl trafficker ring managed by the chief of a casino, Barera (Kurt Gerron). Her ordeal leads her into drug addiction and prostitution. After Karl has served his sentence, he travels to Brazil and, together with the help of the local police, he saves Inge.

Der Weg nach Rio was the last film by Manfred Noa. In terms of its content, the film is an example of the popular white slavery genre. The name of Rio - Rio de Janeiro - in the title refers to Brazil, which was an emerging economic power in Latin America and an important market for the German film industry in the 1920s and 30s. ${ }^{32}$ 
For its premiere in January 1931, Der Weg nach Rio was advertised as 'the first sound film that deals with the dangers of the international trafficking in girls' ${ }^{33}$ However, the abduction of young white women to brothels in 'exotic' areas was already a popular storyline in the silent film era.

The Danish production Den hvide slavinde/The White Slave by Viggo Larsen from 1906 was the first film in the genre and caused an international sensation, paving the way for the genre's worldwide success. ${ }^{34}$ In the following years, a whole series of films with the same or slightly altered titled were produced in Denmark. White slavery was also a popular topic in US productions, such as David W. Griffith's The Fatal Hour (1908) and Traffic in Souls (1913). ${ }^{35}$ In the 1920s, films that dealt with white slavery were considered offensive in the US and a reason for censorship or prohibition. ${ }^{36}$

After World War I, white slavery also became popular in various German film productions. The recent wave of immigration from Eastern Europe and the strong focus on sensational and sexually charged stories - following the lifting of the censorship by the Weimar constitution for a short period (1918-1922) - were most likely important reasons for the films' popularity. ${ }^{37}$ Most of these films are considered to be lost, including the first part of Joe May's Die Herrin der Welt/The Mistress of the World (DE 1919), in which the heroine, played by Mia May, is enslaved by a Chinese brothel; Das Frauenhaus von Brescia/The Woman House of Brescia (Hubert Moest, DE 1920); Das Judenmädel von Sosnowice [The Jewish girl from Sosnowice] (1920) by Ferdinand Walden ${ }^{38}$, and Schamlose Seelen oder ein Mädchenhandel [Shameless souls or a trafficking in girls] (Wolfgang Neff, DE 1922).

After the fight against girl trafficking had officially been included in the statutes of the League of Nations, the last wave of silent films on the subject was shown in Germany from 1927 onwards: Die Frauengasse von Algier [The women alley of Algiers] (DE 1927) by Wolfgang Hoffmann-Harnisch and Jaap Speyer's Mädchenhandel [Trafficking in girls] (DE 1927). The theme is also mentioned in Die Büchse der Pandora/Pandora's Box (DE 1929) by G. W. Pabst, in which Lulu (Louise Brooks) is supposed to be sold to a rich Egyptian for his establishment in Cairo.

The link between the issue of girl trafficking and South America existed before the topic was taken up by the film industry, but its popularity was renewed in 1927 through the publication of Le Chemin de Buenos Aires/The Road to Buenos Aires by the French journalist Albert Londres (1884-1932). Londres' report about the international trafficking in girls was published only a year later in a German version, Der Weg nach Buenos Aires, subtitled Die Geheimnisse des Mädchenhandels (The road to Buenos Aires. The Secrets of the trafficking in girls). In his memoirs, Sergei Eisenstein mentions the idea of adapting Londres' reporting to film, as it was one of his favorite books at that time. ${ }^{39}$ The 


\section{? Südfillm hommt ${ }_{\text {mit dem rechten Film }}$ rechten Zeit !}

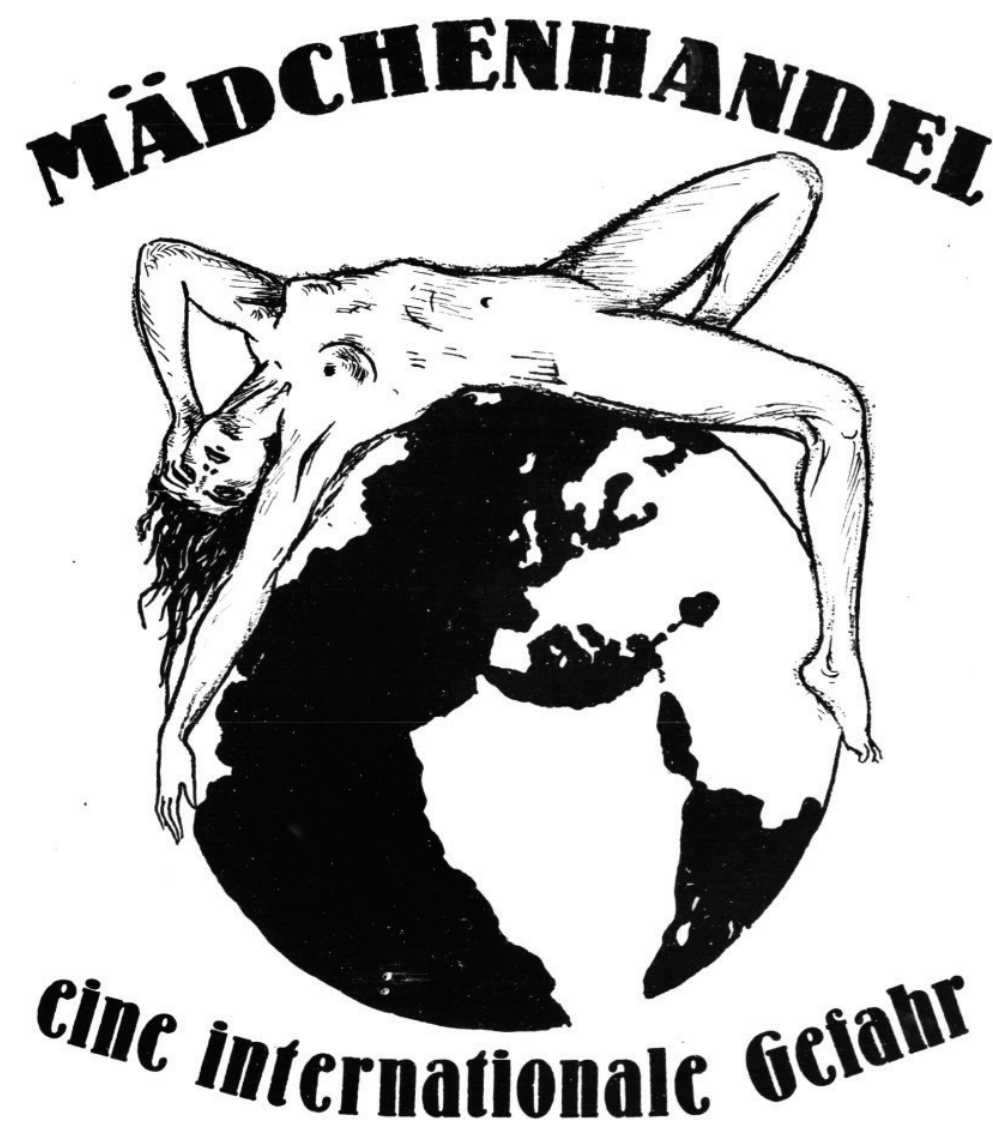

Fabrikat: Liberty-Emelka-Film

Regie: Jaap Speyer

ist ein Sensationserfolg geworden

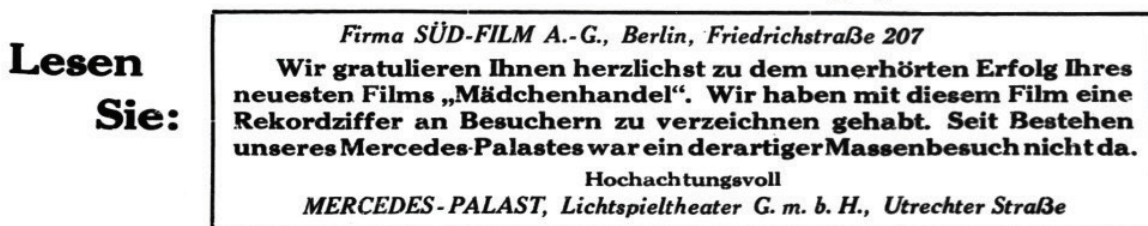

Emelkapalast - Berlin, Kammerlichtspiele -München, Emelkapalast-Köln, Emelkapalast-Leipzig, Germaniapalast -Ber in, Schloßparktheater - Berlin-Steglitz usw. usw.

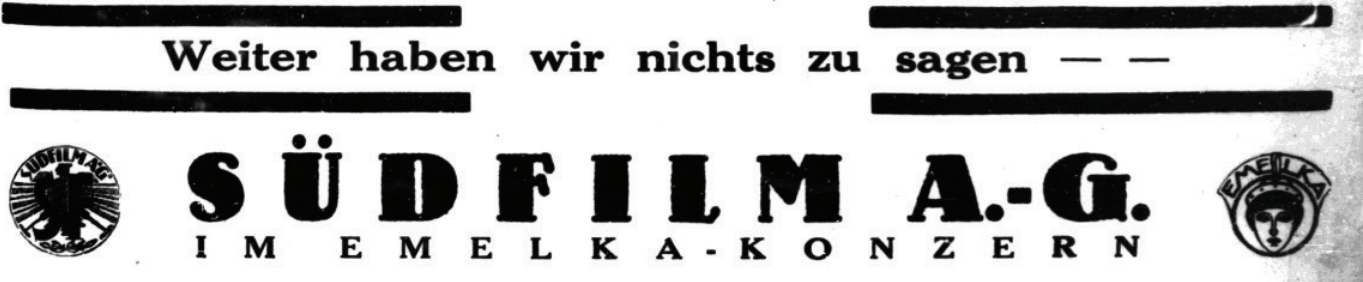


project was never realised, but there were German films that established the link between trafficking in girls and the South American continent: Plüsch and Plümowski /Girls for Sale! (DE 1927) by Hans Steinhoff, Männer ohne Beruf [Men without profession] (Harry Piel, DE 1929), Das Mädchenschiff [The women's boat] (Robert Wohlmuth, AUT/DE 1929) and Tänzerinnen für Südamerika gesucht/Girls for Sale (Jaap Speyer, AUT/DE 1930).

\section{White slavery: An international political task and urban myth}

White slavery was a popular topic due to it being a political issue for every nation. The combat against trafficking in girls was understood as an international task and is documented and illustrated by several reports in the contemporary press and the activities of associations, authorities and institutions. ${ }^{40}$ The first International Congress on Combating Trafficking in Girls in 1899 was followed by several other such congresses. Organisations such as the German National Committee for Combating Girl Trafficking (Deutsches Nationalkomitee zur Bekämpfung des Mädchenhandels) or the Austrian League for Combating Girl Trafficking (Österreichische Liga zur Bekämpfung des Mädchenhandels) were organisations highly committed to education about trafficking in girls and the protection of young women.

Although stories are well documented of young, often Eastern European Jewish women who hoped to find a better life overseas but ended in prostitution, for example in South American brothels, there is no indication of the existence of internationally organised crime gangs that were kidnapping young women from Europe. This part of the story was simply an urban myth. As sociologist Dietmar Jazbinsek remarks, in the early 20th century 'forced prostitution as a form of organized crime never existed. ${ }^{41}$

Journalists and lobbyists, however, did everything they could do to ensure that it existed in the public's mind and claimed that organized trafficking in girls was an international problem. Moreover, white slavery intersected with gender, racist and anti-Semitic discourses. The existence of, amongst others, a Jewish organized crime group, that operated numerous brothels in Argentina and Brazil were eagerly taken up by writers such as Londres and bolstered anti-Semitism in Latin American countries and the rest of the world. ${ }^{42}$ Different to the neutral German term Mädchenhandel (trafficking in girls), the Anglo American term 'white slavery' made it clear that the international fight against trafficking in girls was first of all about the protection of white girls and thus about racial purity. 
For authorities and the public it was important, Jazbinsek notes, to believe in its existence for political reasons because "the horror story about foreign trafficker of girls mobilized resentments and was aimed at against the recognition of prostitution as a profession. ${ }^{43}$ The In addition, stories about trafficking in girls could be used as disciplinary measures against young girls' emancipation and curiosity about the wider world.

Mass media such as film took up the myth of internationally organised white slavery organisations; they kept it alive and refreshed it. Every congress or campaign of the lobby associations resulted in a new boom in the production of white slavery films. ${ }^{44}$ After the premiere of Der Weg nach Rio, the Berliner Volks-Zeitung lamented that the film, unfortunately, again had a special topicality, which was obviously an allusion to the ongoing public discussion on this topic. ${ }^{45}$

Reviews of the film were ambivalent; should the film be taken seriously or viewed with a sense of humour? The Berlin Lokal-Anzeiger commented:

There is supposedly no trafficking in girls, but 'artist agencies', that are looking for dancers for South America. Der Weg nach Rio leads down into the swamp, where it is at deepest. The Film wants to warn, to point out gaps in the law that traffickers get away unpunished when the victim voluntarily rushes into a disaster. The story is not far-fetched, not artificial, not constructed. What you see on the screen has already happened somewhere and can happen any day. ${ }^{46}$

Like other reviewers, Siegfried Kracauer emphasised the 'resumption of this still topical issue', despite disparaging the film as a 'piece from the series of girl trafficker movies' mere moments before. He welcomed the 'realistic milieus' and above all the credible representation of the events, which was 'like an illustration to the report Albert Londres': 'One cannot only learn something from the film, but it is also captivating through its good work. ${ }^{47}$ The Film-Kurier was ironic in tone regarding the accumulation of clichés:

Does anyone believe in a 'noble purpose' of such a trafficker-in-girls-film? The seriousness of its warnings? Not me. Its tendency: make one scary, perplex, catch you, chock you brutally: the majority of cinemagoers is certainly not made up of girls who let themselves be taken to Rio. (...) Old trashy book morality in a new luxury edition. Colportage in bravura technique. The most infamous presented as a noble perfume. (Cinema heart, what do you want more?) T-waanng, T-waanng. ${ }^{48}$ 
Considering the production and the reception context of the film, Der Weg nach Rio is a classic example of popular Weimar cinema. It is a genre film that combines crime with a love story. The film did well at the box office and satisfied the audience's demand for such films. For Brazilian viewers, however, the film was more than disturbing and had little to do with Brazilian reality. Moreover, white slavery never was a popular genre in Brazil. ${ }^{49}$ As the correspondence between German and Brazilian diplomats shows, the film caused a very different reaction on the Brazilian side.

A few days after the premiere, the Brazilian envoy Adalberto Guerra Duval protested at the Foreign Office in Berlin against the defamatory portrayal of Brazil in the film as a refuge for the international trafficking in girls. ${ }^{50}$ Duval reported that he had been invited by a Brazilian journalist to watch the film and that he had a hard time preventing other journalists and Brazilian students, who were living in Berlin, from halting the screening. Duval indicated that further screenings of the film would harm the distribution of German films in Brazil.

Duval was not unaware of the social problem of prostitution in Brazil. In 1913 he represented his country at an international conference against trafficking in girls in London, and he knew about his country's image in the world. ${ }^{51}$ In his eyes, however, a film such as Der Weg nach Rio was not a film that did justice to his country's commitment in this matter, as he explained in a letter of protest to the distributor Südfilm. Guerra Duval expected a statement from the German Foreign Office within a few days that could be sent to Brazil and help respond to potentially negative articles written about the film by Brazilian journalists in Berlin. Guerra Duval could not know that Südfilm already had submitted a request at the Film Review Office to add to Der Weg nach Rio the additional title 'The girl trafficker from Rio'. In a foresighted move, the Film Review Office rejected the request, as it assumed that Brazil could protest the defamatory title. ${ }^{52}$

The German Foreign Office was surprised and concerned about the reaction of the Brazilian envoy and tried to appease the situation. It pointed out to Guerra Duval that it already rejected the additional title but that it also had to follow the jurisdiction of the German Film Act, Lichtspielgesetz. Censorship and the prohibition of a film were in the hands of an independent commission. The Foreign Office could only be an authorised expert to the commission, which did not have to follow the expert's advice. Moreover, the Foreign Office ministry considered the presentation of the Brazilian authorities in the film impeccable, as 'questionable characters among civilians' were shown 'explicitly as foreigners' in the film (so "Italian", "Rumanian”). ${ }^{53}$ Apart from that, the Foreign Office could make no more concessions to the Brazilian envoy and his request. 


\section{Humour versus insult}

How far the opinions about the film diverged is shown by a scene in the film in which Ricardo Gabiano and his lover (Hertha von Walther) have lunch, and the Brazilian housekeeper turns the record of a gramophone with her finger. In contrast to the German Film-Kurier, which called the “"manual operation" of the gramophone' an 'optical joke', the Brazilian press understood the scene as an insult: 'As evidence of our backwardness it is shown how a primitive gramophone is operated through the hand of an old ragged women, she's toothless and leprous. ${ }^{54}$

It was not only the Foreign Office in Berlin that was pressured by Duval's protests. He also sent his complaint to the distributor of the film, the Südfilm A.G. in Berlin, and the producer, the Lothar Stark GmbH. ${ }^{55}$ With an almost threatening undertone Duval finished his letter to the Südfilm by advising them that it was in the company's own interests to immediately stop the film's distribution. Both companies expressed their regret for Duval's impression of the film but rejected his accusation that it disparaged Brazil. ${ }^{56}$

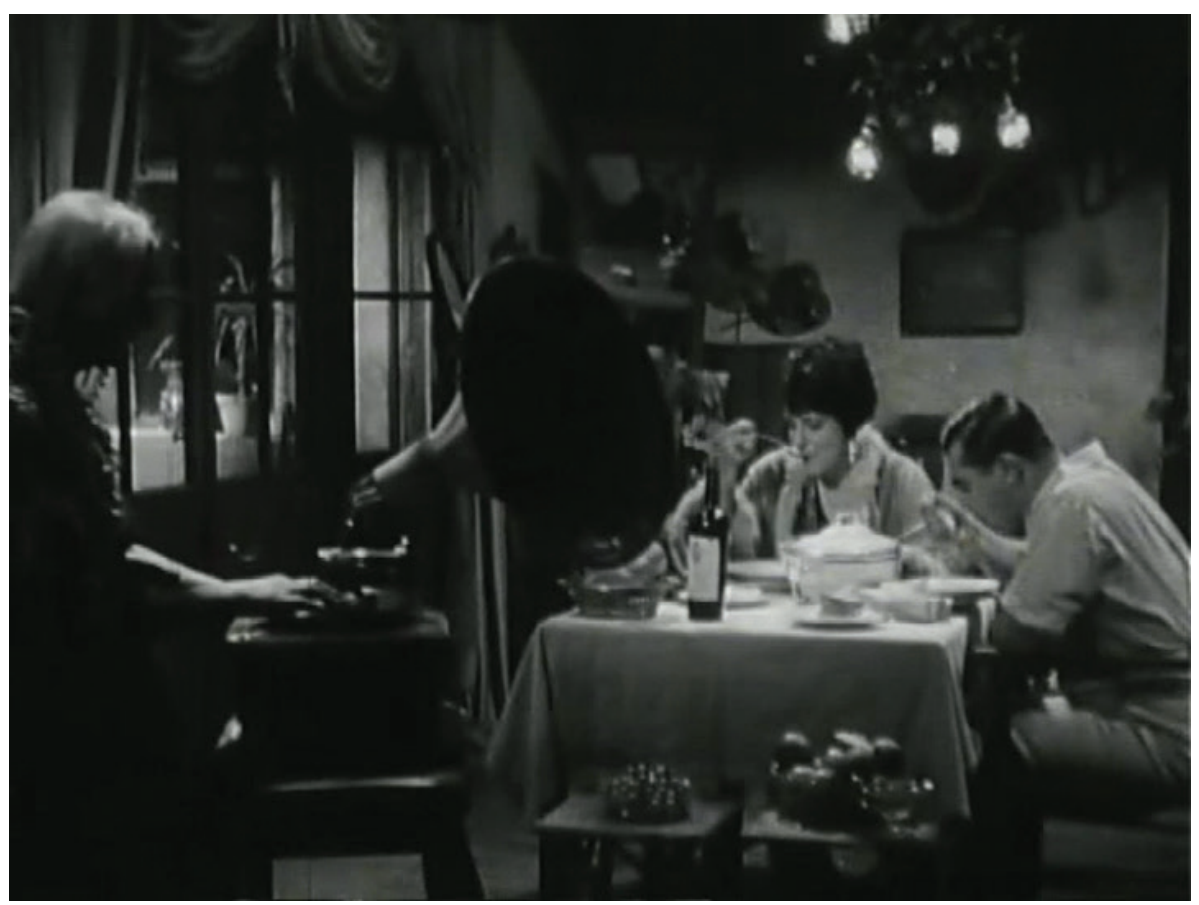

Figure 3. Gramaphon scene: Oskar Homolka (Ricardo Gabiano) and Hertha von Walther (Marietta) in Der Weg nach Rio. 
The Brazilian diplomat's protest was not simply one individual's war against the film, and it was not limited to Berlin. The screening of the film turned from a local conflict into an international one. Duval was in constantly close contact with the Brazilian Foreign Office in Rio de Janeiro in Brazil, which coordinated its action on this matter.

After another meeting with the German Secretary of State Bernhard von Bülow and the handing over of a memorandum by the Brazilian government, Duval again called on the German Foreign Office at the end of February and requested a reply to his complaint from the previous month and a response to Brazil's memorandum. He reiterated that Brazil was ready to immediately ban all German films in Brazil. ${ }^{57}$

Duval was concerned about an imminent diplomatic conflict between Brazil and Germany due to the upcoming release of two films whose titles suggested that they were further white slavery stories: Das gelbe Haus von Rio [The yellow house from Rio] (Karl Grune, DE 1931) as well as Jaap Speyer's Tänzerinnen für Süd-Amerika gesucht. As Speyer’s film took place in Argentina, Duval anticipated a similar conflict between the Berlin Foreign Office and the Argentine embassy.

His concern was partly justified. The Foreign Office assured him that the film plot of Das gelbe Haus von Rio had no relationship whatsoever to Brazil but played in France and meanwhile had been renamed Das gelbe Haus von King Fu [The yellow house of King Fu]. The situation was different with Tänzerinnen für Süd-Amerika gesucht, which premiered on 20 February, 1931. In contrast to Der Weg nach Rio, this white slavery film was made by the National Committee to Combat Trafficking in Girls. ${ }^{58}$ To emphasise authenticity, an advertisement was placed after the performance that stirred up the voyeurism and sensationalism of the audience: '585 public houses! 5000 European prostitutes - from the League of Nations in Buenos Aires detected! The only authentic trafficking in girls film.'59 The German Foreign Office received no complaint from the Argentine embassy, as records of the Argentine Ministry of Foreign Affairs show. ${ }^{60}$

The affair surrounding Der Weg nach Rio, however, continued to spread. Five days after Duval's visit to the German Foreign Office, the German embassy in Rio de Janeiro received a diplomatic note from the Brazilian government in which the film was described as an insult to Brazil. ${ }^{61}$ Whereas the Germans were still trying to settle the matter by way of diplomatic correspondence, on 17 March, 1931, the German government was forced to pay the price for its hesitant attitude. The local dispute that had begun between Guerra Duval and the Foreign Office in Berlin and caused an international diplomatic dispute between the two countries had entered a new stage, that of public national outrage in Brazil. 


\section{From diplomacy to public outrage}

Until March, the Brazilian press paid little attention to the film, despite a short note about it in the daily paper O Jornal in February $1931 .{ }^{62}$ Two months after the film's premiere in Berlin the situation changed. The newspaper Diário de Noticias published the first article about the film's release in Germany, and the diplomatic dispute entered the Brazilian public sphere:

This film work, which according to the program is based on a silly novel of an unknown and most stupid W.E. Friedrich Nietsche [sic] is nothing but a disgrace. A double disgrace, because this film as an expression of the Germans, who are rightly praised for their salutary cultural spirit in film art, is of a downright bleating lowliness; moreover, the film is lying and a stupidinsult against Brazil (...). ${ }^{63}$

In the following days and weeks, the scandal was covered in several newspapers across the wide political spectrum. The left-wing A Esquerda openly called for a boycott: 'We boycott, by our initiative, all films of German origin (...) [and] we show the German filmmakers, that we're not a land of pimps and robbers but a country with people that especially appreciate the feelings of dignity and knows how to ward off attacks on their honour.' ${ }^{64}$

The uproar in the country caused the German Envoy in Rio de Janeiro in March 1931 to recommend to the Foreign Office in Berlin the publishing of articles in German newspapers which showed that the German public was distancing itself from the film and its derogative image of Brazil. It is not known if German authorities followed this advice and encouraged German newspapers to publish the corresponding articles, but in May - four months after the premiere of Der Weg nach Rio - the Berliner Tageblatt adopted Brazil's opinion of the film. In a short article, the paper reported on the incident and supported and called the scandal a 'moral fiasco’ for Germany:

Foreign countries cannot tolerate such foolish games (Läpperei) in the long run. In German film Vienna only exists as a suburb of Grinzing, Paris only as a revue city, the Balkans as the domicile of operetta princes and Rio and Buenos Aires only as centres of white slavery. (...) One should finally stop the mendacity which harms the own business, even if the censorship here keeps an eye shut. With their products, German film companies provoke abroad. ${ }^{65}$ 
The situation in Berlin then worsened; the pressure of the Brazilian government producing its first results. Südfilm and the production company Lothar Stark offered to discontinue the German and international distribution of Der Weg nach Rio. The copies still circulating in Germany were supplemented with an opening credit that showed the exemplary role of Brazil in its fight against the trafficking of girls. ${ }^{66}$ In addition, Südfilm offered the distribution throughout Germany of documentaries about Brazil, in particular about Rio de Janeiro. ${ }^{67}$ The effort was in vain. By order of the Brazilian Foreign Office in May 1931, the Ministry of Economic Affairs prohibited the import of all films of the distributor Südfilm and the Lothar Stark GmbH until further notice. ${ }^{68}$

\section{More than just a film}

In retrospect one may be surprised at the reaction of the Brazilian government. Was the reaction to the film's story of the Brazilian envoy Guerra Duval exaggerated? Why did the press, both right and left-wing, react so harshly to a simple genre film that was neither shot nor even shown in Brazil?

A first answer is given by a newspaper cutting in the records of the Brazilian embassy. The embassy archived a short article from the Berliner Tageblatt that reported on the protest of the Reich Union of German Movie House Owners, Reichsverband deutscher Lichtspieltheaterbesitzer, against the distribution of Hell's Angels (Howard Hughes, USA 1930) in Germany. ${ }^{69}$ The Brazilian government was quite aware that Germany too was concerned about its image in foreign films.

Second, Brazil's cultural politics was about to change in the 1930s. This bears comparison with another German white slavery film released in August 1928 in Brazil: O Tráfico das Brancas [The trade with whites] (Hans Steinhoff, DE 1928). The film is an adaptation of Norbert Jacques's novel Plüsch und Plümowski from 1927. It was shown in Germany under the same title Plüsch und Plümowski or Das Frauenhaus von Rio [The women's house from Rio], and Die Hölle von Rio. Mädchenschicksale [The hell of Rio. Girls' fates $].{ }^{70}$ There was no outrage on the part of the Brazilian embassy or press at the time of the film's release in Germany or Brazil. O Tráfico das brancas was simply discussed as a German drama in the Brazilian film magazine $A$ Scena Muda. ${ }^{71}$

To understand the full context of Brazil's rejection of a film such Der Weg nach Rio, it is important to investigate in more detail who motivated Guerra Duvall to see the film in Berlin. The journalist who published the article that initiated the public outrage in Brazil in March 1931 was Ildefonso Falcão. Falcão was not only working as a journalist; he also was a novelist, poet and, most important, a Brazilian 
diplomat working for the Brazilian government. Falcão started his diplomatic career in 1918 and was working in Brazil's diplomatic service in Berlin since 1926. He was appointed Consul $2^{\text {nd }}$ class for the Brazilian Consulate in Cologne in January 1931. The German government briefly considered refusing the recognition of his diplomatic status based on his article. As he had excellent relations with Brazil's Foreign Minister, his exequatur was not denied. ${ }^{72}$

With his article, which appeared shortly before he took office in Cologne in April 1931, Falcão introduced himself to the Brazilian public as a defender of Brazilian values abroad. He was probably also aware that the public discussion generated by his article would put the Brazilian government under pressure in its reaction to Germany.

About his work as consul in Cologne, it is reported that Falcão was obsessed with the idea that when the Germans heard about Brazil, they imagined a country of 'Indios' and not a country where European culture thrived. ${ }^{73}$ For him, Brazil was 'the great unknown in the modern world'. ${ }^{74}$ He wanted it to be recognised for its cultural achievements in the world, and films about white slavery stood in the way of its ascension to the pantheon of cultural nations. Therefore, it was 'time for those outside to know us through our achievements so that they will stop seeing us as a vast taba [small village of indiginous people] of savage Indians and illiterate half-breeds. ${ }^{75}$

Falcão was not a critic of Germany. On the contrary, he was a fervent admirer of German culture. During his time in Germany, he regularly wrote about German culture, actors, films, cities and music, and regularly published in the Brazilian intellectual journal Careta. However, Falcaõ's accusation of Germany and the Western World's degrading, racist view on Brazil as a mere location for simplistic cinematographic fantasies is a double-edged sword. ${ }^{76}$

In his articles he emphasised Brazilian national pride but neither explained for what this pride was standing for nor did he defend Brazil's ethnic and cultural diversity. Considering his bourgeois education, his diplomatic career and the reiteration of Western prejudices when describing Brazil, one can ask, if the image of Brazil that Falcão was thinking of was that of a white Brazil. That Falcão stumbled over his own prejuduces shows his convoluted discourse and antiSemitic remarks in his commitment for German Jewish refugees that were applying for visa to Brazil during his time as a consul in Germany. To Brazilian authorities he argued that the Jewish immigrants that applied for visa did not display the 'reprochable features of the [Semitic] race', but they personified 'the Aryan mentality and work ethic at its best' and therefore would strengthen Brazilian economy. ${ }^{77}$ 
Historians Juliette Dumont and Anaïs Fléchet point out that during Brazil’s First Republic (1899-1930) 'there was no systemic policy for disseminating Brazilian culture abroad. ${ }^{78}$ To improve its cultural relations with other nations, Brazil joined the League of Nation's International Committee on Intellectual Cooperation in 1925. His strong interest in promoting Brazilian culture made Falcão in the years that followed, an advocate of Brazilian president Getulio Vargas' culture ideological project Estado Novo (New State), which was aimed at securing Brazil its place among the modern, civilized nations. ${ }^{79}$ The significance of this intellectual exchange resulted in the establishment of the Intellectual Expansion Service, Serviço de Expansão Intelectual, in Brazil, of which Falcão became one of the first heads from 1935-1936.

According to Falcão, the service 'meant to present Brazil in all its cultural aspects. This service will publicize every Brazilian cultural achievement and will thus foster intellectual cooperation with the modern world educated community'. ${ }^{80}$

Der Weg nach Rio was more than just a European genre film. For the Brazilian public, it was an example of the European nations' bias against a Latin American nation, and Falcão planned to put an end to this. Brazil's next step in the diplomatic debate, however, also had unexpected consequences for the country.

\section{The Brazilian import ban}

In the hope that the Brazilian government would abandon its decision, the Südfilm decided in June to change the title of the film to Die Grüne Kugel [The green globe], delete all Brazilian references in the film and revise the entire advertising material. For German authorities, the company's offer seemed to settle the case ${ }^{81}$, but the Brazilian government stuck to its ban.

The outrage about a German film that was never shown in Brazilian cinemas began in the coming years to affect the distribution of German films in Brazil

It took more than a year until the film scandal was revisited by the Brazilian press. Entries in the Hemeroteca Brasileira show that, similar to the discussion in spring 1931, several Brazilian newspapers reported about Der Weg nach Rio in September and October $1932 .{ }^{82}$ This time they did not discuss the film's story but rather the economic and cultural consequences of the film's ban. The debate was triggered by the film Dreyfus (Richard Oswald, DE 1930), one of the most successful German films of the 1930/31 season, which dealt with the Dreyfus affair in France at the end of the 19th century. 
The film was distributed by Südfilm, and by chance Brazilian customs recognised the logo of the company when a Brazilian film entrepreneur tried to import the film for his cinemas. Brazilian newspapers argued that the government made the mistake of equating the distribution company to the production company. The newspaper O Jornal criticised the ignorance of the Brazilian government. Due to the ban, Brazilian viewers would be excluded from watching important films that dealt with historical events and would no longer participate in international cultural discussions. ${ }^{83}$ Lothar Stark productions such as Scampolo, ein Kind der Strasse/A Girl of the Street (Hans Steinhoff, DE 1932) and Madame ne veut pas de enfants [My wife does not want have children] (Constantin Landau, Hans Steinhoff, DE 1933), as well as Südfilm films such as Berlin Alexanderplatz (Phil Jutzi, DE 1931), had an international distribution but were not accessible to the Brazilian audience. It is impossible to say to what extent the ban influenced the import of German films to Brazil, but the ban not only harmed Brazilian exhibitors but also the Brazilian cinema audience, putting them at a disadvantage to other countries and audiences.

The reassessment of the incident in the press did not end the ban, which was not lifted until March 1933. However, the exhibition of Der Weg nach Rio, which probably caused one of the most serious cultural-diplomatic tensions in the diplomatic history between Germany and Brazil, remained prohibited.

\section{Conclusion}

A multi-dimensional and multi-perspective approach, as has been presented in this article and case study, is a promising approach for exploring new terrain in film and in New Cinema History. Historians agree that it is difficult if not impossible to master all aspects of Werner and Zimmermann's elaborated approach. ${ }^{84}$ Histoire croisée, therefore, should be understood as an attempt to mediate between cultural transfer and historical comparison rather than as a programme that can be implemented in research practice. ${ }^{85}$

The case study on Der Weg nach Rio demonstrates how the combination of German and Brazilian perspectives gives the film a very complex meaning, from genre to politics, politics to press coverage, and to Brazilian cultural politics.

The distribution and exhibition history of Der Weg nach Rio the film is a perfect example of how decisions made in Brazil influenced the film's history in Germany. For German-Brazilian 
relations, Der Weg nach Rio was a disaster in diplomatic and public communication. It also shows that the asymmetrical relationship between the two nations, in political or economic terms, does not necessarily mean that the 'weaker' nation, economically speaking, had no way to react to the 'stronger' one. Brazilian authorities had a very strong response to the film's exhibition in Germany, and Brazil's reaction to the film's exhibition found strong support in the Brazilian and the German press, something that was not expected by German authorities. However, the public outrage in Brazil also had far-reaching consequences for the Brazilian film market and the Brazilian film audience.

Finally, understanding Der Weg nach Rio from a Brazilian perspective places the film in a very different light. Usually considered a typical genre film of its time, the contextualisation of the film within Brazilian culture and cultural politics changes the understanding of the film to the one that stood at the beginning of the investigation.

Werner and Zimmermann emphasise the aspect of reflexivity in the histoire croisée approach. Whether one investigates the film's history from the German or the Brazilian perspective, 'one obtains perspectives, and thus interpretations, that are quite different. ${ }^{86}$

Researching Der Weg nach Rio as a European popular genre not only changes its character if viewed from a Brazilian perspective, but it also encourages the investigation of two somehow interrelated questions: What is the role and relation between film and public diplomacy, and, regarding Rick Altman's genre analysis, 'what can genre teach us about nations'? ${ }^{87}$

Research on this film has demonstrated that the history of Der Weg nach Rio goes beyond a traditional production-distribution-exhibition history. Rather, the film's history is the result of conflictual international relations. It is also not a singular event in the diplomatic correspondence between Germany and other nations. Correspondence between the German Foreign Office and Argentina, Chile, Ecuador and Venezuela that were studied parallel to this investigation show that film was a recurring topic in diplomatic affairs. Further research could therefore corroborate the significance of this under-researched aspect and integrate public diplomacy into cinema history.

Second, and following Rick Altman's conclusion that genres are like nations - they are not closed systems but, amongst others, must be open to changes and modifications - one could add the significance of asking for the relationship between genres and a nation's cultural identity. As was argued, films of the white slavery genre were shown in Brazil but not viewed 
within the context of the white slavery discourse, as was the case in Europe. The example of O Tráfico das Brancas shows how, just a couple of years earlier, another film of this genre was not interpreted as a national insult. This raises the question of how much does politics influence discursive shifts in a nation's popular culture, and what do genres tell us about cultural characteristics?

It remains to be noted that after the premiere of Der Weg nach Rio, the German film journal Der Kinematograph predicted a whole series of other Rio films to come. ${ }^{88}$ However, there was only one film that dealt with white slavery in the following years - Kampf um Blond: Mädchen, die spurlos verschwinden [Fight for blonde: Girls that disappear without a trace] (Jaap Speyer, DE 1933). Rio or South America was no longer the location in the film's story. By locating the narrative to the fantasy location of Zagossa in the Orient, the German government could be sure that no foreign diplomat would knock on the door the next day and demand the film be banned, at least none from South America anyway.

\section{Notes}

1 Ildefonso Falcão, “Um film injurioso ao Brasil e á sua civilização," Diário de Notícias, March 17, 1931. http:// memoria.bn.br/DocReader/DocReader.aspx?bib=093718_01\&PagFis=4391\&Pesq=Weg\%20nach\%20Rio.

2 The article is an expanded and revised version of "Diplomaten contra Mädchenhändler. Der deutschbrasilianische Streit um Manfred Noas Spielfilm Der Weg nach Rio (1931)," Filmblatt 66, 2018, 52-69.

3 Where available, the article uses the official English distribution titles. If not available, the translation is given in square brackets.

4 Daniel Biltereyst, Thunnis van Oort, Philippe Meers, “Comparing Historical Cinema cultures,” in The Routledge Companion to New Cinema History, ed. Daniel Biltereyst, Richard Maltby, and Philippe Meers (New York: Routledge, 2019), 96.

5 https://bndigital.bn.gov.br/hemeroteca-digital/

6 Biltereyst, van Oort, Meers, “Comparing Historical Cinema Cultures,” 96.

7 Heinz-Gerhard Haupt and Jürgen Kocka, "Preface," in Comparative and Transnational history: Central European Approaches and New Perspectives, ed. Heinz-Gerhard Haupt and Jurgen Kocka (New York, Oxford: Berghahn, 2009), 19.

8 Hartmut Kaelble, “Comparative and Transnational History,” Ricerche di Storia Politica, October 2017, 24. 
9 Georg Christ, Saskia Dönitz, Daniel G. König et al., Transkulturelle Verflechtungen: Mediävistische Perspektiven (Göttingen: Universitätsverlag Göttingen, 2016), 64. https://doi.org/10.17875/gup2016-981.

10 Jürgen Kocka, “Comparison and Beyond," History and Theory 42 (February 2003): 39-44.

11 Michael Werner and Bénédicte Zimmermann, “Beyond Comparison: Histoire Croisée and the Challenge of Reflexivity," History and Theory 45, no. 1 (2006): 30-50. DOI: https://doi.org/10.1111/j.1468-2303. 2006.00347.

12 Werner and Zimmermann, "Beyond Comparison," 50.

13 Ibid.

14 Marie Cronqvist and Christoph Hilgert, "Entangled Media Histories. The Value of Transnational and Transmedial Approaches in Media Historiography,” Media History, 23, no. 1 (2017): 130-141. http://dx.doi. org/10.1080/13688804.2016.1270745.

15 Werner and Zimmermann, “Beyond Comparison,” 31-32.

16 Ibid., 47.

17 Ibid., 38.

18 Daniel Biltereyst and Philippe Meers, "New Cinema History and the Comparative Mode: Reflections on Comparing Historical, Cinema Cultures,” Alphaville: Journal of Film and Screen Media, 11 (2016), 13-32, http://www.alphavillejournal.com/Issue11/ArticleBiltereystandMeers.pdf. Accessed March 5, 2020.

19 Politisches Archiv, Auswärtiges Amt, Berlin (PA AA), R 78933.

20 Joseph S. Nye, Soft Power: The Means to Success in World Politics (New York: Public affairs. 2004), x.

21 Nye, Soft Power, 5.

22 Patrick Major, “Shooting Rommel: The Desert Fox (1951) and Hollywood's Public-Private Diplomacy,” Historical Journal of Film, Radio and Television 39, no.2 (2018): 209-232, https://doi.org/10.1080/01439685 .2018.1522791; Paola Voci and Luo Hui, ed., Screening China’s Soft Power (London: Routledge, 2018); Roopa Swaminathan, Bollywood boom: India's Rise as a Soft Power (Gurgaon, Haryana, India: Penguin Books India, 2017).

23 Juliette Dumont and Anaïs Fléchet, "Brazilian Cultural Diplomacy in the Twentieth Century," Revista Brasileira de História 34, no. 67 (2014), https://doi.org/10.1590/S0102-01882014000100010.

24 “Imigração alemã no Brasil," Instituto Brasileiro de Geografia e Estatistica - IBGE, https://brasil500anos. ibge.gov.br/territorio-brasileiro-e-povoamento/alemaes.html.

25 Luiz Alberto Moniz-Bandeira, Wachstumsmarkt Brasilien. Der deutsche Wirtschaftsund Handelsbeitrag in Geschichte und Gegenwart. 2nd edition (Wiesbaden: Springer Gabler 2013), 15. 
Karl Wolffsohn ed., Jahrbuch der Filmindustrie. 4. Jahrgang 1928/1929 (Berlin: Lichtbild-Bühne, 1930), 278.

27 Kristin Thompson, Exporting Entertainment: America in the World Film Market 1907-34 (London: Bfi Publishing, 1985), 77.

28 Thompson, Exporting Entertainment, 139.

29 Flaviano Bugatti Isolan, Das páginas à tela: Cinema alemão e imprensa na década de 1930 (Porto Alegre e Santa Cruz do Sul) (Porto Alegre: UNISC, 2006).

30 Wolfgang Fuhrmann, "A Ufa no Brasil: cinemas, empresários, e audiências," Anais do Textos Completos do XXII Encontro da SOCINE 2018 (Saõ Paulo: Socine, 2018), 1084-1089.

31 Wolfgang Fuhrmann, "Deutsche Kultur- und Spielfilme in Brasilien der 1930er Jahre Eine transnationale Perspektive,” in Film - Kino - Zuschauer: Filmrezeption / Film - Cinema - Spectator: Film Reception, ed. Irmbert Schenk, Margrit Tröhler, and Yvonne Zimmermann (Marburg: Schüren, 2010), 399-418.

32 Fuhrmann, "Deutsche Kultur- und Spielfilme.“

33 Der Montag, No. 3, January 19, 1931.

34 Dietmar Jazbinsek: “Der internationale Mädchenhandel. Biographie eines sozialen Problems,” Schriftenreihe der Forschungsgruppe Metropolenforschung des Forschungsschwerpunkts Technik - Arbeit - Umwelt am Wissenschaftszentrum Berlin für Sozialforschung, No. FS II 02-501, 2002, 54, https://www. econstor.eu/handle/10419/49624. Accessed March 5, 2020.

35 Brian Donovan, White Slave Crusades: Race, Gender, and Anti-Vice Activism, 1887-1917 (Champaign: University of Illinois Press, 2005).

36 William Marston Seabury, Motion Picture Problems. The Cinema and the League of Nations (New York: The Avondale Press, 1929), 199, 309, 384, 387. White slavery in film was also a reason for import ban and censorship in the United Kingdom. Seabury, Motion Picture Problems, 393.

37 Sabine Hake, German National Cinema, second edition (New York: Routledge, 2008), 33.

38 Walden's film story is based on contemporary reports that the number of Jewish girls with a poor economic background from Galicia in Eastern Europe was disproportionately high among the victims of white slavery.

39 Sergej M. Eisenstein: Yo, ich selbst. Memoiren. Bd. 1, Revised Edition (Berlin: Henschelverlag 1998), 336 and 572.

40 A historical overview gives Stefanie Lauben, Weißer Markt. Frauenhandel und Völkerrecht vom Ausgang des 19. Jahrhunderts bis zur Mitte des 20. Jahrhunderts. (Marburg: Tectum Verlag, 2014).

41 Jazbinsek: “Der internationale Mädchenhandel,” Summary, unpag. (p. 3). 
42 Donna J. Guy, Sex \& Danger in Buenos Aires: Prostitution, Family, and Nation in Argentina (Lincoln, London: University of Nebraska Press, 1992), 123-125.

43 Jazbinsek: “Der internationale Mädchenhandel,” Summary.

44 Michael Esser, “Fesselnde Unterhaltung. Mit weißen Sklavinnen zu neuen Ufern,” in: Schwarzer Traum und weiße Sklavin. Deutsch-dänische Filmbeziehungen 1910-1930, ed. Manfred Behn (München: Edition Text + Kritik, 1994), 55-62, specifically 61.

45 F.: “Der Weg nach Rio,"Berliner Volks-Zeitung, January 17, 1931.

46 -sch.: “Der Weg nach Rio,"Berliner Lokal-Anzeiger, January 16, 1931.

47 Siegfried Kracauer: "Berliner Filmchronik," Frankfurter Zeitung, Jan 21, 1931, in: Werke. Bd. 6.2: Kleine Schriften zum Film 1928-1931. ed., Inka Mülder-Bach (Frankfurt a. Main: Suhrkamp, 2004), 441.

E. J. (Ernst Jäger), “Der Weg nach Rio,” Film-Kurier, no. 15, January 16, 1931. Unless otherwise indicated, all translations from German or Portuguese are those of the author.

49 I would like to thank film and cinema historians João Luiz Vieira and Rafael de Luna from Universidade Federal Fluminense, Niterói - Rio de Janeiro, Brazil for this important information.

50 Record, January 23, 1931, PA AA, R 78933. Brazil had already taken diplomatic action against films that violated the country's reputation or misrepresented the country before 1931. Seabury mentions a protest by the Brazilian ambassador in Washington in 1927, who 'kindly warned' the American film producers in this respect. Seabury, Motion Picture Problems, 79.

51 Guerra Duval to Südfilm A. G. from January 23, 1931, PA AA, R 78933.

52 Record from Jan 23, 1931, PA AA, R 78933.

53 Aufzeichnung, January 26, 1931, PA AA, R. 78933.

54 E. J. "Der Weg nach Rio," and Diário de Notícias, March 17, 1931. Translation according to the German translation of the German Embassy in Rio de Janeiro, March 18, 1931, PA AA, R 78933.

55 Guerra Duval to Südfilm, January 23, 1931. Arquivo Histórico do Itamaraty, Rio de Janeiro, Missões Diplomaticas Brasileiras (AHI/MDB), 4/2/13.

56 Letter from the lawyers of Südfilm to Guerra Duval, January 28, 1921 [sic], Letter from Lothar Stark G.m.b.H. to Guerra Duval January 28, 1931. AHI/MDB, 4/2/13. Document, Von Bülow, February 23, 1931, PA AA, R 78933.

58 Advertisement for Tänzerinnen für Süd-Amerika gesucht in Film-Kurier, February 10, 1931.

59 Ibid.. 
60 A study of the records of the Argentine Ministry of Foreign Affairs in Buenos Aires, Archivo Histórico de Cancillería y Culto, does not show any evidence for an Argentine protest. However, the Brazilian journal Careta reports that the original title of the film was supposed to be 'The Way to Buenos Aires' and was changed after a protest letter from the Argentine embassy to 'The Way to Rio'. "Der Weg nach Rio...," Careta 1186, March 14, 1931: 30. http://objdigital.bn.br/acervo_digital/div_periodicos/careta/ careta_1931/careta_1931_1186.pdf. Accessed March 5, 2020. http://memoria.bn.br/DocReader/ docreader.aspx?bib=083712 \&pasta=ano\%20193 \&pesq=Der\%20Weg\%20Nach\%20Rio.

61 Telegram from the German Embassy in Rio de Janeiro to the Foreign Office in Berlin, February 28, 1931, PA AA, R 78933.

62 “Notas estrangeiras”. In: O Jornal, February 26, 1931. http://memoria.bn.br/DocReader/DocReader. aspx?bib=110523_03\&pesq=Der\%20Weg\%20noch\%20RIo\&pasta=ano\%20193

63 Falcão, “Um film injurioso ao Brasil.”

64 "Deante dos filmes injuriosos ao Brasil, produzidos na Allemanha, a dignidade nacional exige a boycottagem absoluta da producção cinematographic allemã,” A Esquerda, March 21, 1931, http:// memoria.bn.br/DocReader/docreader.aspx?bib=297984\&pasta=ano\%20193\&pesq=Der\%20Weg\%20 nach\%20Rio.

65 “Brasilien protestiert gegen deutsche Mädchenhändler-Filme,” Berliner Tageblatt, May 14, 1931, AHI/MDB, 4/2/13.

66 Note verbale, May 4, 1931, AHI/MDB, 4/2/13.

67 Ibid.

68 Circular no. 27, May 9, 1931, in: Diário Oficial, May 12, 1931.https://www.jusbrasil.com.br/diarios/1937451/ pg-8-secao-1-diario-oficial-da-uniao-dou-de-12-05-1931?ref=serp. The ban on films by the Lothar Stark Ltd., which at first seems to have been neglected, is evident from Diário Oficial, August 10, 1932, https:// www.jusbrasil.com.br/diarios/2199305/pg-7-secao-1-diario-oficial-da-uniao-dou-de-10-08-1932?ref=serp.

69 “Gegen einen Hetzfilm,” Berliner Tageblatt, June 18, 1931, AHI/MDB, 4/2/13.

70 On the production of Plüsch und Plümowski, Horst Claus, Filmen für Hitler. Die Karriere des NS-Starregisseurs Hans Steinhoff. (Wien: Verlag Filmarchiv Austria, 2013), 151-155.

71 “O Tráfico das brancas,” A Scena Muda 385 (1928): 6-7, 10, 34. http://memoria.bn.br/pdf/084859/per084859_ 1928_00385.pdf. “O Tráfico das brancas,” A Scena Muda 386, (1928): 23-25, 33. http://memoria.bn.br/pdf/ 084859/per084859_1928_00386.pdf. Accessed March 5, 2020,

72 Telegram of the German Embassy in Brazil to the Foreign Office, April. 11, 1931, PA AA, R 78933. 
73 Antonio Alexandre Bispo, “Inauguração do Instituto Português-Brasileiro de Colonia (1934) na sua inserção política," Revista Brasil-Europa - Correspondência Euro-Brasileira, 124/4 (2010), http://www. revista.brasil-europa.eu/124/Instituto_Portugues-Brasileiro.html.

74 Ildefonso Falcão, “Cooperacão Intellectual,” Careta (November 16, 1935): 20-21, http://objdigital.bn.br/ acervo_digital/div_periodicos/careta/careta_1935/careta_1935_1430.pdf. Accessed July 10, 2020.

75 Juliette Dumont and Anaïs Fléchet, "Brazilian Cultural Diplomacy in the Twentieth Century.'Pelo que é nosso!': a diplomacia cultural brasileira no século XX,” Revista Brasileira de História 34, no. 67 (June 2014). In an article for Careta in 1935, Falcao comes back to his Berlin experience in the context of the Paramount production Brazen aka Fatal Lady (Edward Ludwig, US 1936) and Donongoo Tonka (Reinhold Schünzel, DE 1936). Ildefonso Falcao, “A injuria grosseira pelo film,”Careta (October 3, 1936): 20-21. http://objdigital. bn.br/acervo_digital/div_periodicos/careta/careta_1936/careta_1936_1476.pdf. Accessed July 10, 2020.

77 Mordecai Paldiel, Diplomat Heroes of the Holocaust (Jersey City: KTAV Publishing House, Inc., 2007), 226.

78 Dumont and Fléchet, “Brazilian Cultural Diplomacy,” 3.

79 Ibid.

80 Falcão quoted in Juliette Dumont, “From Intellectual Cooperation to Cultural Diplomacy: the Brazilian and Chilean experiences (1918-1946),” Does Academic Exchange Matter? Cultural Diplomacy, Scholarly Internationalism, and American Studies since World War II, organized by the Austrian-American Educational Commission (Fulbright), November 2011, Vienna, Austria, https://halshs.archives-ouvertes.fr/ halshs-00601507.

81 Correspondence, June 5, 1931, Annexo ao ofício no. 32, de 28 de junho de1931, AHI/MDB, 4/2/13.

82 The discovery of the topic's resumption by the Brazilian press was only possible through the database of the Hemeroteca Brasileira. In addition to entries in newspapers from Rio de Janeiro, the capital city, the regional newspaper from the state of Santa Catarina also reported on the case. "Accão do Ministro Franco Mello," A Noticia, October 14, 1932, http://memoria.bn.br/DocReader/docreader.aspx?bib=843709\& pasta=ano\%20193\&pesq=Lothar\%20Starke.

83 “A prohibição do film Dreyfus para o territorio brasileiro," O Jornal, September 24, 1932, http://memoria. bn.br/DocReader/docreader.aspx?bib=110523_03\&pasta=ano\%20193\&pesq=Filmreich.

84 Pierre-Yves Saunier, “Going Transnational? News from Down Under: Transnational History Symposium,” Canberra, Australian National University, September 2004.

85 Debora Gerstenberger and Cláucio Serra Domingues, "Vergleich, Transfer, Histoire Croisée im Spannungsfeld von Religion und Politik, 1500 bis 2000”, https://www.hsozkult.de/conferencereport/id/tagungsberichte-3763. 
86 Werner and Zimmermann, "Beyond Comparison," 49.

87 Rick Altman, “What Can Genres Teach Us About Nations?,” in Film/Genre (London: British Film Institute, 1999), 195-206.

88 'Der Weg nach Rio,' Der Kinematograph, January 17, 1931.

\section{Biography}

Wolfgang Fuhrmann studied film and television studies at the Ruhr-University Bochum and the University of Amsterdam. In 2003 he wrote his dissertation about German colonial cinematography at the University of Utrecht. From 2005-2008 he was Principal Investigator of the DFG Research Project 'Film and Ethnography in Germany 1900-1930'. From 2008 to 2017 he was Assistant Professor at the Department of Film Studies, University of Zurich and has held teaching positions in Germany, Switzerland, and the Americas. He has published on German colonial cinema, early ethnographic filmmaking, historical film reception, cinema history, Latin American Cinema, and transnational film history. He is currently living in Colombia.

TMG Journal for Media History

Volume 23 No $(1 / 2) / 2020$

DOI

https://doi.org/10.18146/tmg.590

PUBLISHER

Netherlands Institute for Sound and Vision

\section{COPYRIGHT}

Each article is copyrighted (c) by its author(s) and is published under license from the author(s). When a paper is accepted for publication, authors will be requested to agree with the Creative Commons Attribution 4.0 International License. 